Steigmann (26) on the other hand suggested that aldehydes and amino-sugars derived from the mucopolysaccharides present in gelatin reduced the gold salt to form sensitising gold specks. Other studies by Hautot and Sauvenier (27) of the chemical composition of sensitivity specks, fog nuclei and latent image centres showed that these centres could be both metallic or ionic in character depending on how the emulsion was prepared. Many other workers in this field, including Faelens (28) of AgfaGevaert, have made valuable contributions to the study of the mechanism, but a thorough review of this intriguing phenomenon is beyond the scope of this article. However, the evidence does suggest that more than one mechanism may take place; the gold ion can interact with latent image silver to form gold atoms which catalyse development, and gold sulphide produced during ripening may act as positive hole acceptors with gold ions serving as effective electron traps.

\section{Conclusion}

For over a century now gold has played a very important role in the evolution of photography, from the days when photography was more of an art to the present time when emulsion preparation and coating constitutes very much of a science. Perhaps gold will find other uses in photography in the years to come.

What is certain, however, is that any developments in crystal physics which will add greater insight to the mechanism of gold sensitisation and latent image formation must benefit our future theory and practice of emulsion making.

\section{References}

1 W. C. Nelson, U.S. Patent 1,849,245

2 C. J. Blay, Amat. Photog., 1946, 96, (Jan. 16), 39

3 F. Formstecher, Photog. Ind., 1922, 17, 378; 18, 403

4 Namias, Eder's Handbuch Photog., 1928, 4

5 R. W. Henn and D. G. Wiest, Photog. Sci. Engng., 1963, 7, (5), 253-261

6 J. I. Crabtree et al., PSA J., 1940, 6, (4)

7 R. W. Henn and B. D. Mack, Photog. Sci. Engng., 1965, 9, (6), 378-384

8 T. H. James et al., $P S A \mathcal{F} ., 1948,14,349$

9 T. H. James, F. Colloid Sci., 1948, 3, 447-455

10 T. H. James and W. Vanselow, $P S A$ Y., 1949, 15, 688

11 F. A. Hamm and J. J. Comer, F. Appl. Phys., 1953, 24, (12), 1495-1513

12 (a) E. J. Wall, "Photographic Emulsions" Chapman \& Hall Limited, 1929; (b) T. Baker, "Photographic Emulsion Techniques", Chapman \& Hall Limited, 1949

$13 \mathrm{~K} . \mathrm{V}$. Chibisov and A. A. Mikhailova, Kino-Foto-Khim. Prom., 1937, (3), 24

14 S. E. Sheppard, Photog. F., 1925, 65, 380; Br.F. Photog. $1925,72,481$

15 F. Kropff, Photog. Ind., 1925, 42, 1145

16 B. H. Carroll and D. Hubbard, F. Res. Nat. Bur. Stds., $1928,1,565-588$

17 B. Kankelwitz, German Patent 618,354

18 W. Jenisch, $Z$. Wiss. Photog., 1926, 24, 248

19 A. Charriou and S. Valette, Sci. Ind. Photog., 1935, 2, (6), 395

20 U. Schmieschek, German Patent 692,828

21 R. Koslowsky, Z. Wiss. Photog., 1951, 46, (4-6), 65-72

22 (a) A. P. H. Trivelli and W. F. Smith, British Patent 636,140 ; (b) J. A. Leermakers, E. H. Hewitson and E. C. Yackel, British Patent 636,234; (c) C. Waller, R. B. Collins and E. C. Dodd, British Patent 570,393

23 P. A. Faelens, Sci. Ind. Photog., 1956, 27, (4), 121-122

24 (a) F. W. H. Mueller 7. Opt. Soc. Am., 1949. 39, (6), 494-496; (b) F. W. H. Mueller, Photog Sci. Engng., $1966,10,(6), 338-343$

25 F. W. H. Mueller, PSA F., 1950, 16, 46

26 A. Steigmann, Sci. Ind. Photog., 1955, 26, (8), 289-304

27 A. Hautot and H. Sauvenier, Sci. Ind. Photog., 1957, 28, (2), 57-65

28 P. A. Faelens, Photog. Korresp., 1968, 104, (7), 137-146

\title{
Soviet Research on Organogold Complexes
}

The chemistry of organogold complexes is attracting increasing attention in a number of countries. The strength of the effort devoted to coordination chemistry in the Soviet Union is well known, so that a report of work on gold carried out at the Moscow State University named for $M$. V. Lomonosov is particularly interesting. A. N. Nesmeyanov, E. G. Perevalova, K. I. Grandberg, and D. A. Lemenovskii (Izv. Akad. Nauk S.S.S.R., Ser. Khim., 1974, (5), 1124-1137) have recently surveyed this field, concentrating on their own extensive researches.

Although $\mathrm{Au}^{\mathrm{III}}$ complexes have been known since 1907 , and $\mathrm{Au}^{\mathrm{I}}$ complexes only since 1959 , it is the latter on which most work is being done. $\mathrm{Au}^{\mathrm{I}}$ can form $\pi$-complexes with unsaturated compounds, it can form isonitrile, ylide and carbene complexes, it can expand its coordination sphere to encompass neutral ligands such as phosphines, and it forms compounds with $\mathrm{Au}-\mathrm{Au}$ bonds, e.g. polynuclear $\mathrm{Au}^{\circ}$ clusters.
Three methods of synthesis of $\mathrm{Au}^{\mathrm{I}}$ compounds are described; synthesis with the assistance of organolithium and organomagnesium compounds, the aurination of carbonyl compounds, and synthesis of one organogold compound from another. The synthesis of $\mathrm{Au}^{\mathrm{III}}$ compounds is described more briefly.

Considerable attention has been paid to the effect of $\mathrm{Au}-\mathrm{C}$ bonds in $\mathrm{RAuPR}_{3}$ compounds and their reactions with electrophilic reagents. The reaction of vinyl(triphenylphosphine)gold with potassium permanganate is described and the existence of tris(triphenylphosphinegold)oxonium salts is demonstrated.

${ }^{+} \mathrm{AuPR}_{3}$ cations show affinity for mild Lewis bases. Furthermore, systematic studies of $\mathrm{RAuPR}_{3}^{\prime}$ compounds disclosed new binuclear organogold cationic complexes $\left[\mathrm{R}\left(\mathrm{AuPR}_{3}{ }_{3}\right)\right]^{+} \mathrm{X}^{-}$and oxonium complexes $\left[\left(\mathrm{R}_{3}^{\prime} \mathrm{PAu}\right)_{3} \mathrm{O}\right]^{+} \mathrm{X}^{-}$. The syntheses, structures and reactions of these complexes are considered in detail. F. J. $\mathrm{s}$. 